\title{
KESIAPAN PENERIMAAN TEKNOLOGI BAGI DOSEN DALAM MENGADOPSI IMISSU DI UNIVERSITAS UDAYANA
}

\author{
Ade Devia Pradipta1) \\ Putu Titah Kawitri Resen ${ }^{2)}$ \\ Program Studi Ilmu Komunikasi ${ }^{1)}$ \\ Program Studi Ilmu Hubungan Internasional ${ }^{2)}$ \\ Fakultas Ilmu Sosial dan Ilmu Politik \\ Universitas Udayana \\ Email: deviapradipta88@unud.ac.id
}

\begin{abstract}
ABSTRAK
IMISSU merupakan sebuah sistem terintegrasi milik Universitas Udayana yang bertujuan untuk mewujudkan self service technology pada organisasi. Dosen sebagai salah satu pengguna IMISSU diharapkan mampu mendokumentasikan kegiatannya dengan memanfaatkan IMISSU. Namun, sebelum seorang individu memutuskan untuk menerima atau menolak sebuah teknologi, kesiapan mereka untuk menerima teknologi menjadi satu hal yang penting. Penelitian ini bertujuan untuk menjelaskan kesiapan dosen di Universitas Udayana untuk mengadopsi IMISSU sebagai sebuah inovasi. IMISSU merupakan sistem terintegrasi milik Universitas Udayana unutk mempermudah civitas akademika dalam melakukan pekerjaan. Sebanyak 157 dosen yang memiliki akun dan menggunakan IMISSU secara reguler menjadi sampel dalam penelitian ini. Kesiapan dosen dalam mengadopsi IMISSU diukur dengan menggunakan Indeks Kesiapan Teknologi yang meliputi empat dimensi, yaitu optimism, keinovatifan, ketidaknyamanan, dan ketidakamanan. Penelitian ini menggunakan metode survey dan data dianalisis secara deskriptif kuantitatif. Hasil penelitian ini menemukan bahwa ratarata skor untuk keempat dimensi adalah tinggi. Hal ini berarti bahwa dosen di Universitas Udayana memiliki pandangan positif terhadap IMISSU sebagai sebuah inovasi. Namun, perasaan ketidaknyamanan masih ada karena kompleksitas fitur IMISSU.
\end{abstract}

Kata kunci: dosen, IMISSU, Indeks Kesiapan Teknologi.

\section{ABSTRACT}

IMISSU is an integrated system ini Udayana University which help organization to create self service technology. Lecturers as one of the IMISSU's user were expected to keep their activities in IMISSU. However, it is important to measure the readiness to adopt or reject the technology. The aim of this study is to describe the readiness of lecturers in Udayana University to adopt IMISSU as an innovation. IMISSU is an integrated system in Udayana University to help organization's member work easier. The subject of this study was 157 lecturers who had account in IMISSU and used IMISSU regularly. The readiness of lecturers to adopt IMISSU was measured by Technology Readiness Index, which is included four dimensions, optimism, innovativeness, discomfort, and insecurity. Survey technique was used and the data were analyzed by descriptive quanitative. This study found that the average scores for all dimensions were high. It means the lecturers were accepted IMISSU as an innovation positively. In other side, they still felt uncomfortable with the features of IMISSU because of its complexity.

Key words: IMISSU, Lecturer, Technology Readiness Index. 


\section{PENDAHULUAN}

Tri Dharma Perguruan Tinggi merupakan kewajiban utama yang harus dilakukan oleh setiap dosen setiap semesternya. Tri Dharma Perguruan Tinggi yang meliputi Pendidikan dan Pengajaran, Penelitian, Pengabdian kepada masyarakat, dan Penunjang Tri Dharma, mewajibkan setiap dosen untuk mencapai angka 12 SKS setiap semester. Tri Dharma Perguruan Tinggi setiap semester ini akan dibuat menjadi satu laporan kinerja yang disebut dengan Beban Kerja Dosen. Setiap dosen, baik swasta maupun negeri, wajib membuat laporan Beban Kerja Dosen untuk menunjukkan kinerja mereka dalam satu semester. Laporan Beban Kerja Dosen ini memiliki beberapa tujuan, yaitu: 1) meningkatkan profesionalisme dosen dalam melaksanakan tugas; 2) meningkatkan proses dan hasil pendidikan; 3) menilai akuntabilitas kinerja dosen di perguruan tinggi; 4) meningkatkan atmosfer akademik di semua jenjang perguruan tinggi; dan 5) mempercepat terwujudnya tujuan pendidikan nasional.

Sejak tahun 2016, Universitas Udayana telah memberlakukan sistem sistem pendokumentasian kegiatan secara terintegrasi. Sistem ini dilakukan secara online melalui sebuah sistem terintegrasi yang secara teknis berada di bawah koordinasi Unit Sumber Daya Informasi (Borang Universitas Udayana, 2016). Demi memudahkan pengintegrasian kegiatan civitas akademika, Universitas Udayana telah memiliki sebuah sistem yang disebut dengan IMISSU. IMISSU atau Integrated Management Information System the Strategic of Udayana merupakan sebuah sistem berbasis layanan SSO (Single Sign On). Sistem ini mengintegrasikan lebih dari 30 sistem untuk menjalankan manajemen kampus (www.unud.ac.id). Dengan semakin berkembangan teknologi, dosen diharapkan mampu mendokumentasikan kegiatannya dengan memanfaatkan teknologi, terutama IMISSU.

IMISSU diharapkan mampu mewujudkan self-service technology bagi civitas akademika. Interaksi tatap muka antar civitas akademika, terutama yang berkaitan dengan hal-hal administratif, dapat dikurangi. Hal ini disebabkan karena Self-service technology dapat mempertahankan competitive advantage sebuah organisasi (Ho \& Ko, 2008). Lin \& Hsieh (2006 dalam Ho \& Ko, 2008) menyatakan bahwa individu mampu menaklukkan ketakutan mereka terhadap Self service Technology dan sudah mengakses teknologi tersebut, mereka masih memiliki kekhawatiran dan kegelisahan untuk menggunakan layanan tersebut. Kegelisahan ini berkaitan dengan kompleksitas (perceived complexity), risiko, dan kesulitan untuk mengakses layanan mengarahkan mereka untuk menolak menggunakan teknologi tersebut. Namun, sebelum seorang individu memutuskan untuk menerima 
atau menolak sebuah teknologi, penting diketahui kesiapan mereka untuk menerima inovasi, terutama yang berkaitan dengan teknologi.

Penerapan IMISSU sebagai sebuah sistem informasi terintegrasi merupakan salah satu pemenuhan akan tuntutan beradaptasinya Universitas Udayana terhadap perkembangan teknologi informasi dan komunikasi. Harapannya, penerapan teknologi dalam kegiatan-kegiatan organisasi akan membuat kinerja organisasi menjadi lebih efektif dan efisien. Namun, terkadang penerapan teknologi baru akan menimbulkan ketidakpastian bagi anggota organisasi. Hal yang sama terjadi pada penerapan IMISSU.

Hasil observasi di lapangan menunjukkan bahwa sebagian besar dosen masih kesulitan untuk menggunakan IMISSU. Hal ini disebabkan karena IMISSU merupakan sebuah inovasi yang baru diberlakukan oleh Universitas Udayana mulai awal tahun 2016. Namun, banyakanya fitur yang dimiliki oleh IMISSU cenderung membingungkan dosen ketika digunakan untuk mendokumentasikan kegiatan dalam satu semester. IMISSU yang terus berbenah hampir setiap semester membuat dosen memiliki kegelisahan dan kekhawatiran untuk menggunakan sistem ini. Melihat fenomena tersebut, menjadi penting bagi Universitas Udayana untuk mengetahui kesiapan para dosen dalam mengadopsi IMISSU. Hal ini menjadi penting karena tingginya kesiapan dalam mengadopsi IMISSU akan mengurangi resistensi dosen terhadap IMISSU. Ketika dosen telah siap dalam mengadopsi teknologi tersebut, maka IMISSU akan lebih mudah didifusikan dan diadopsi dalam berbagai kegiatan yang berkaitan dengan Tri Dharma Perguruan Tinggi. Dengan demikian, efektivitas kinerja Universitas Udayana dapat tercapai.

Konsep Kesiapan penerimaan teknologi (Technology Readiness) mengacu pada kecenderungan individu untuk mengenal dan menggunakan teknologi untuk mencapai tujuan hidup dan pekerjaan, yang diukur melalui Indeks kesiapan penerimaan teknologi (Parasuraman, 2000). Indeks ini mencakup empat dimensi, yaitu optimism, innovativeness, discomfort, dan insecurity. Indeks ini digunakan untuk mengetahui keyakinan umum dan pertimbangan yang diambil individu untuk menerima teknologi (Tsikriktsis, 2004). Parasuraman (2000), menyatakan bahwa tingkat kesiapan individu untuk mengadopsi sebuah inovasi dipengaruhi oleh optimisme atau keyakinan mereka bahwa teknologi tersebut akan memberikan manfaat substansial baginya. Selain itu, kesiapan individu untuk mengadopsi teknologi, juga dipengaruhi oleh kecenderungan individu untuk menjadi pionir dalam 
menerima ide-ide baru dalam sebuah sistem sosial. Technology Readiness dapat dilihat sebagai keseluruhan cara pikir yang dihasilkan dari pendorong dan penghambat mental individu yang secara bersamaan akan menentukan kecenderungan seseorang untuk menggunakan teknologi baru (Parasuraman, 2000).

Kesiapan individu maupun organisasi diukur dengan indeks kesiapan teknologi (Technology Readiness index). Indeks ini digunakan untuk mengetahui keyakinan umum dan pertimbanganpertimbangan yang diambil individu untuk menerima teknologi. Indeks ini memiliki empat dimensi, yaitu: optimism, inovativeness, discomfort, dan insecurity (Tsikriktsis, 2004). Optimism menggambarkan adanya pandangan positif terhadap teknologi, seperti kontrol, fleksibilitas, kenyamanan, dan efisiensi. Inovativeness berkaitan dengan kecenderungan individu untuk menjadi pemimpin opini dan pionir teknologi. Discomfort menggambarkan situasi dimana individu tidak mampu memanipulasi teknologi, dan merasa kebingungan dengan kompetensinya. Insecurity berkaitan dengan ketidakpercayaan individu terhadap teknologi dan potensinya untuk bekerja dengan baik (Yieh, Chen, \& Wei, 2012). Dimensi ini mengacu pada keyakinan bahwa interaksi yang dilakukan dengan menggunakan teknologi tidak akan memberikan nilai tambah.Optimism dan innovativeness merupakan dimensi kontributor atau pendorong kesiapan penerimaan teknologi. Sebaliknya, discomfort dan insecurity merupakan dimensi penghambat kesiapaan penerimaan teknologi.Technology Readiness Index terdiri dari 28 item pengukuran yang terbagi kedalam empat dimensi yang telah disebutkan sebelumnya. Dimensi Optimism terdiri dari 10 item, Innovativeness 5 item, discomfort 8 item, dan insecurity sebanyak 5 item.

Parasuraman \& Colby (2001 dalam Tskriktsis, 2004) menyebutkan terdapat lima tipe technology customers, yaitu: explorers, pioneers, skeptics, paranoids, dan laggards. Dalam kaitannya dengan dimensi TRI, lima tipe technology customers tersebut dapat dikategorikan menjadi seperti berikut:

\begin{tabular}{|c|c|c|c|c|}
\hline $\begin{array}{c}\text { Technology } \\
\text { Segments }\end{array}$ & Optimism & Innovativeness & Discomfort & Insecurity \\
\hline Explorers & Tinggi & Tinggi & Rendah & Rendah \\
\hline Pioneers & Tinggi & Tinggi & Tinggi & Tinggi \\
\hline Skeptics & Rendah & Rendah & Rendah & Rendah \\
\hline Paranoids & Tinggi & Rendah & Tinggi & Tinggi \\
\hline Laggards & Rendah & Rendah & Tinggi & Tinggi \\
\hline
\end{tabular}




\section{Metode}

Penelitian ini menyasar dosen Universitas Udayana baik perempuan maupun laki-laki yang telah memiliki dan menggunakan IMISSU. Objek yang diteliti adalah tingkat adopsi dosen Universitas Udayana dan tingkat kesiapan mereka dalam menggunakan IMISSU sebagai sistem informasi yang terintegrasi. Sampel ditentukan menggunakan proportionate stratified random sampling, dimana strata yang digunakan adalah fakultas. Jumlah sampel yang diambil adalah $10 \%$ dari populasi. Total populasi dosen di Universitas Udayana berjumlah 1571 orang, sehingga sampel dalam penelitian ini adalah 157 orang.

Variabel yang diukur dalam penelitian ini adalah Technology Readiness yang diukur dengan Technology Readiness Index. Dalam penelitian ini, indikator yang digunakan berjumlah 38 indikator. Secara operasional, Technology Readiness dapat didefinisikan sebagai kecenderungan dosen Universitas Udayana untuk mengenal dan mengadopsi teknologi baru berupa IMISSU yang digunakan untuk mencapai tujuan dalam dunia kerja. Variabel ini akan diukur dengan menggunakan empat dimensi, yaitu:

a) Optimism, pandangan positif dosen Universitas Udayana terhadap IMISSU dan meyakini bahwa IMISSU akan meningkatkan kontrol, fleksibilitas, dan efisiensi dalam mendokumentasikan kegiatan selama satu semester.

b) Innovativeness, kecenderungan dosen Universitas Udayana untuk menjadi pionir dan pemimpin opini dalam penggunaan IMISSU.

c) Discomfort, perasaan ketidakmampuan untuk melakukan kontrol terhadap teknologi IMISSU dan merasa sangat tergantung pada teknologi tersebut.

d) Insecurity, ketidakpercayaan dan skeptis terhadap kemampuan IMISSU untuk bekerja dengan maksimal.

\section{HASIL DAN PEMBAHASAN}

IMISSU atau Integrated Management Information System of UNUD

(https://imissu.unud.ac.id/) merupakan sebuah sistem informasi terintegrasi yang berada dalam naungan Unit Sumber Daya Informasi (USDI). USDI merupakan sebuah wujud keseriusan dan komitmen dari pimpinan UNUD dalam rangka menciptakan sistem terintegrasi dalam hal penguatan bidang teknologi informasi. IMISSU yang memiliki visi "Bersatu Membangun Universitas Udayana” 
didirikan untuk membuat pendokumentasian dan pengelolaan informasi yang berkaitan dengan civitas akademika menjadi lebih baik. IMISSU merupakan sebuah sistem yang erat dengan pengembangan, penataan, dan pengintegrasian sistem informasi ke dalam suatau layanan SSO (Single Sign On). Dengan model seluruh sistem informasi yang ada di lingkungan Universitas Udayana diintegrasikan dalam konteks pengelolaan user, integrasi sistem informasi dan data di level database, dan integrasi bisnis proses. Dalam IMISSU, Single Sign On (SSO) merupakan ujung tombak kemajuan integrasi sistem UNUD. Dalam SSO ini, seluruh civitas akademika baik dosen, mahasiswa, dan pegawai harus memiliki akun untuk $\log$ in ke dalam sistem. Untuk memiliki akun, seluruh civitas akademika Universitas Udayana harus didaftarkan oleh operator SIMAK di setiap fakultas. Seluruh data yang telah masuk ke IMISSU akan terkoneksi langsung dengan PD Dikti Feeder.

Kesiapan penggunaan IMISSU pada dosen Universitas Udayana diukur dengan menggunakan Indeks Kesiapan Teknologi. Berdasarkan hasil perhitungan, ditemukan bahwa bahwa responden cenderung memiliki pandangan positif yang tinggi terhadap teknologi IMISSU. Hal tersebut terlihat dari rata-rata skor dari 9 indikator dimensi optimism yang mencapai angka 3,55. Secara umum, responden cenderung optimis terhadap keberadaan IMISSU sebagai teknologi baru.

Tabel 2. Hasil Perhitungan Dimensi Kesiapan Penerimaan Teknologi IMISSU

\begin{tabular}{|l|c|c|}
\hline \multicolumn{1}{|c|}{ Dimensi } & $\begin{array}{c}\text { Rata- } \\
\text { rata }\end{array}$ & Kategori \\
\hline Optimism & $\mathbf{3 , 5 5}$ & Tinggi \\
\hline Innovativeness & $\mathbf{3 , 1 9}$ & Sedang \\
\hline Discomfort & $\mathbf{2 , 9 7}$ & Sedang \\
\hline Insecurity & $\mathbf{2 , 6 8}$ & Sedang \\
\hline
\end{tabular}

Sumber: data diolah, 2017

Selanjutnya, adalah dimensi innovativenes yang merupakan kecenderungan individu untuk menjadi pemimpin opini dan pionir teknologi. Secara umum, kecenderungan responden untuk menjadi pionir dan pemimpin opini dalam penggunaan IMISSU adalah cukup tinggi atau sedang. Hal ini ditunjukkan dengan skor rata-rata pada dimensi ini adalah 3,19. Pada dimensi discomfort, terlihat bahwa rata-rata skor untuk dimensi discomfort adalah 2,97. Angka ini memiliki arti bahwa ketidak mampuan responden untuk melakukan kontrol terhadap teknologi IMISSU cukup tinggi. Dengan demikian, bisa dinyatakan bahwa responden memiliki ketergantungan yang cukup tinggi pada 
IMISSU. Dimensi ini berkaitan dengan situasi dimana individu tidak mampu memanipulasi teknologi, dan merasa kebingungan dengan kompetensinya.

Pada dimensi insecurity, dapat dilihat bahwa rata-rata skor untuk dimensi ini adalah 2,68, yang artinya ketidakpercayaan responden terhadap ketidakmampuan IMISSU untuk bekerja dengan maksimal cukup tinggi. Dengan demikian, responden berpendapat bahwa meskipun IMISSU membantu pekerjaan mereka menjadi efisien, masih ada ketidakpercayaan terhadap kemampuan IMISSU untuk bekerja maksimal dalam membantu pekerjaan mereka sebagai dosen. Keempat dimensi kesiapan penerimaan teknologi ternyata memiliki rata-rata skor yang cukup tinggi. Bahkan dimensi optimism memiliki rata-rata skor sebesar 3,55 yang artinya responden memiliki pandangan yang positif terhadap penggunaan IMISSU. Jika dikaitkan dengan lima tipe technology customers oleh Demirci \& Ersoy (2008), rata-rata skor yang tinggi pada semua dimensi menunjukkan responden berada pada kategori pioneers.

Kesiapan Penerimaan Teknologi merupakan sebuah konsep yang mengacu pada kecenderungan individu untuk mengenal dan menggunakan teknologi untuk mencapai tujuan hidup dan pekerjaan, yang diukur melalui Indeks Kesiapan Penerimaan Teknologi (Parasuraman, 2000). Tingkat kesiapan individu dalam mengadopsi sebuah teknologi dipengaruhi oleh optimisme individu bahwa teknologi tersebut akan memberikan manfaat substantial baginya. Selain itu, kecenderungan individu untuk menjadi pionir dalam menerima ide-ide baru dalam sebuah sistem sosial juga mempengaruhi penerimaan teknologi (Parasuraman, 2000). Berdasarkan hasil jawaban responden pada bagian sebelumnya, ditemukan bahwa rata-rata skor untuk setiap dimensi adalah 3,55 untuk optimism, 3,19 untuk innovativeness, 2,97 untuk discomfort, dan 2,68 untuk insecurity. Angka-angka tersebut menunjukkan bahwa hanya pada dimensi optimism yang memperoleh nilai tinggi, sedangkan tiga dimensi lainnya hanya berada pada rentang sedang atau cukup tinggi. Demirci \& Ersoy (2008) dalam pengkategoriannya tentang technology customers menyatakan bahwa jika semua dimensi mendapatkan skor yang tinggi, maka individu tersebut masuk dalam kategori pionir. Dalam hal ini, responden memiliki pandangan yang positif terhadap IMISSU dan menyadari bahwa sistem tersebut membantu pekerjaan mereka menjadi lebih efisien. Selain itu, responden juga cenderung mampu untuk menjadi pemimpin opini dan pionir ketika menggunakan IMISSU. Namun, responden merasa bahwa mereka belum mampu memanipulasi IMISSU karena banyaknya fitur dan rumitnya sistem tersebut sehingga mereka sering merasa kebingungan. Ditambah lagi, responden merasa bahwa inovasi dalam 
IMISSU dianggap mengancam beberapa pihak karena keterampilan mereka dianggap usang. Responden juga berpendapat bahwa penggunaan IMISSU tidak memberikan mereka nilai tambah.

Kesiapan penerimaan teknologi berkaitan dengan bagaimana kemampuan individu untuk menerima sebuah inovasi. Sebuah inovasi akan mampu terdifusi jika individu dalam sistem sosial telah siap untuk mengadopsi inovasi tersebut. Dalam konteks IMISSU, yang dapat dikategorikan sebagai inovasi adalah IMISSU itu sendiri sebagai sebuah sistem terintegrasi. Rogers (2003) menyatakan bahwa terdapat lima atribut untuk mengukur tingkat adopsi sebuah inovasi, yaitu manfaat relatif, kesesuaian, kompleksitas, dapat diuji coba, dan dapat diobservasi. Pada manfaat relatif, berdasarkan hasil tabulasi reponden ditemukan bahwa IMISSU dianggap lebih baik daripada teknologi sebelumnya yang digunakan. Hal ini terlihat dari jawaban responden pada dimensi optimism yang cenderung merasa positif dan puas terhadap IMISSU. Kesesuaian berkaitan dengan sejauh mana IMISSU dianggap sesuai dengan nilai-nilai yang dianut, pengalaman masa lalu, dan kebutuhan dari adopter potensial. Dari jawaban responden dapat dilihat bahwa IMISSU sudah mampu memenuhi kebutuhan mereka, terutama dalam hal dokumentasi dan digitalisasi kegiatan. IMISSU juga dianggap telah sesuai dengan visi dan misi Universitas Udayana.

Dalam proses adopsi sebuah inovasi, terdapat beberapa tahapan yang disebut dengan the innovation-decision process. Tahapan ini meliputi tahap pengetahuan, tahap persuasi, tahap pengambilan keputusan, tahap implementasi, dan tahap konfirmasi. Pada sosialisasi IMISSU, USDI sebagai unit yang membawahi IMISSU menggunakan saluran personal kepada dosen dan juga komunikasi massa melalui website universitas dan juga workshop ke seluruh fakultas yang ada di lingkungan Universitas Udayana. Hal ini dilakukan agar seluruh dosen memiliki informasi yang cukup ketika menggunakan IMISSU. Dengan kata lain, tahap pengetahuan telah dilalui oleh dosen sebagai adopter IMISSU. Tahap berikutnya adalah persuasi, yang mana individu akan aktif mencari informasi yang lebih terperinci dan akurat mengenai IMISSU. Pada tahap ini, dosen mempertimbangkan manfaat dan kelemahan IMISSU untuk membuat keputusan apakah akan menolak atau mengadopsi IMISSU. Namun, mengingat penggunaan IMISSU merupakan sebuah kewajiban dari pihak universitas, maka seluruh dosen wajib mengadopsi IMISSU, meskipun belum semua dosen mengetahui informasi yang rinci tentang IMISSU. Dalam hal ini, USDI dan pihak universitas lebih aktif untuk mmpersuasi dosen. 
Tahap ketiga adalah tahap pengambilan keputusan. Namun, adanya instruksi universitas membuat semua dosen untuk mengambil keputusan yang sama, yaitu mengadopsi IMISSU. Tahap selanjutnya adalah tahap implementasi. Pada tahap ini, individu mengevaluasi hasil adopsi dan tetap mempelajari inovasi secara lebih akurat. Berkaitan dengan IMISSU, responden menyatakan bahwa mereka memiliki pandangan yang positif terhadap penggunaan IMISSU. Hal ini dapat dilihat dari skor rata-rata dimensi optimism yang tinggi, yaitu sebesar 3,55. Tahap terakhir dalam difusi inovasi adalah tahap konfirmasi, yang mana pada tahap ini, individu mencari konfirmasi terhadap keputusannya mengenai inovasi. Evaluasi yang dilakukan pada tahap ini pada akhirnya akan menentukan apakah individu akan melanjutkan adopsi atau berhenti. Meskipun evaluasi terhadap IMISSU terus dilakukan oleh responden, namun responden memiliki peluang yang kecil untuk berhenti melakukan adopsi. Hal ini merupakan konsekuensi dari adanya instruksi dari universitas untuk wajib menggunakan IMISSU dalam dokumentasi kegiatan akademik. Berdasarkan penjelasan di atas ditemukan bahwa semua tahap adopsi inovasi telah dilalui oleh responden. Namun, evaluasi responden terhadap IMISSU masih penting dilakukan untuk semakin meningkatkan sikap positif responden terhadap IMISSU dan menurunkan ketidaknyamanan mereka terhadap inovasi seperti IMISSU di masa yang akan datang.

\section{SIMPULAN}

Berdasarkan hasil perhitungan ditemukan bahwa skor rata-rata pada keempat dimensi indeks kesiapan penerimaan teknologi berada pada kategori tinggi dan sedang. Keempat skor dimensi tersebut termasuk dalam kategori pioneers, karena skor pada dimensi optimism yang tinggi berarti responden memiliki pandangan yang positif terhadap penggunaan IMISSU. Namun, responden masih memiliki ketidaknyamanan terhadap IMISSU karena masih rumit dan kompleksnya fitur-fitur yang ada pada IMISSU. Berdasarkan tahap-tahap adopsi inovasi, ditemukan bahwa pada IMISSU, responden telah melalui tahap pengetahuan, tahap persuasi, tahap pengambilan keputusan, tahap implementasi, dan tahap konfirmasi. Proses pada tahap-tahap ini dapat dilalui semuanya secara lebih cepat karena sifat adopsi IMISSU yang merupakan instruksi dari universitas. Namun, diperlukan panduan manual yang lebih sederhana dan lebih mudah dipahami ketika muncul fitur-fitur baru pada IMISSU. Panduan ini menjaadi krusial bagi pengguna, terutama pengguna yang tidak terlalu akrab dengan teknologi. Selanjutnya, sebaiknya dilakukan evaluasi terhadap indikator yang digunakan agar menghasilkan instrumen yang lebih valid dan reliabel. 


\section{Referensi}

Benbasat, Izak and Gary C. Moore. 1991. "Development of an Instrument to Measure the Perception of Adopting and Information Technology Innovation”. Information System Research. Vol. 2: No. 3. Page: 192-222.

Cooper, Donald R. dan C. William Emory, 1998. Metode Penelitian Bisnis. Edisi Kelima. Jakarta: Erlangga.

Demirci, Ahmet Emre and Nezihe Figen Ersoy. 2008. “Technology Readiness Innovative High-Tech Products: Hw Consumers Perceive and Adopt New Technology". The Business Review, Cambridge. Vol: 11. December, No. 1. Page 302-309.

Ho, Shu-Hsun and Ying-Yin Ko. 2008. "The Effects of Self-service Technology on Customer Value and Customer Readiness: The Case of Internet Banking”. Internet Research. Vol.8: No. 4. Page 427-446.

Indriantoro, Nur dan Bambang Supomo. 2002. Metodologi Penelitian Bisnis: Untuk Akuntansi dan Manajemen. Edisi Pertama: Yogyakarta: Badan Penerbit Fakultas Ekonomi UGM.

Jogiyanto, Muhammad dan Willy Abdillah. 2009. Konsep dan Aplikasi PLS (Partial Least Square) untuk Penelitian Empiris. Yogyakarta: Badan Penerbit Fakultas Ekonomi UGM.

Kriyantono, Rachmat. 2006. Teknis Praktis Riset Komunikasi. Jakarta: Kencana. Littlejohn, Stephen W dan Karen A. Foss. 2009. Teori Komunikasi. Edisi Sembilan. Jakarta: Salemba Humanika.

Minishi-Majanja, Mabel K. and Joseph Kiplang'at. 2005. “The Diffusion Of Innovations Theory As A Theoritical Framework In Library And Information Science Research". Journal of Library and Information Science. Vol. 71: No. 3. Page: 211-224.

Neuman, W. Lawrence. 2014. Social Research Methods: Qualitative and Quantitative Approaches. Seventh Edition. Essex: Pearson.

Parasuraman, A. 2000. "Technology Readiness Index (TRI): A Multiple-Item Scale to Embrace New Technologies". Journal of Service Research. Vol. 2: No. 4. Page: 307-320.

Rogers, Everett M. 2003. Diffusion of Innovations. sFifth Edition. New York: The Free Press.s , 1986. Communication Technology: The New Media in Society. New York: The Free Press.

Sekaran, Uma and Roger Bougie. 2009. Research Methods for Business: A Skill Building Approach. West Sussex: Wiley.

Sugiyono. 2008. Metode Penelitian Bisnis. Bandung: Alfabeta.

Taylor, Steven A, Kevin Celuch, and Stephen Goodwin. 2002. "Technology Readiness in the eInsurance Industry: An Exploratory Investigation and Developmentof an Agent Technology eConsumption Model. Journal of Insurance Issues. Vol. 25: No. 2. Page: 142-165. 
Tsikriktsis, Nikos. 2004. "A Technology Readiness-Based Taxonomy on Customers: A Replication and Extension". Journal of Service Research. Vol. 7: No. 1. Page: 42-52.

Universitas Udayana. 2016. Borang Akreditasi Institusi Universitas Udayana: Standar 4. Jimbaran: Universitas Udayana.

Yieh, Kaili., Jiun-shan Chen, and Maggie Biwei Wei. 2012. "The Effects of Technology Readiness on Customer Perceived Value: An Empirical Analysis". Journal of Family and Economic Issues. Vol. 33. Page 177-183.

Survei Kepuasan Pengelolaan SDM Unud. 2016.

https://www.unud.ac.id/in/bincang1173-IMISSU-Bersatu-Membangun-UNUD-.html.Diakses pada 2 Februari: 14.00 Wita. 